\title{
Evaluation of Gastroprotective Activity of Qarahine: A Polyherbal Formulation
}

\author{
Iqra Asad', Irfan Anjum², Alamgeer ${ }^{3}$, Haseeb Ahsan', Muhammad Naveed Mushtaq ${ }^{2, *}$ \\ ${ }^{1}$ Department of Pharmacology, Lahore College of Pharmaceutical Sciences, Lahore, PAKISTAN. \\ ${ }^{2}$ Faculty of Pharmacy, The University of Lahore, Lahore, PAKISTAN. \\ ${ }^{3}$ Department of Pharmacology, University College of Pharmacy, University of the Punjab, Lahore, PAKISTAN. \\ ${ }^{4}$ College of Pharmacy, University of Sargodha, Sargodha, PAKISTAN.
}

\begin{abstract}
Background and Aim: Qarahine, a polyherbal formulation consisting of natural active ingredients, is used to treat peptic ulcer. The aim of the present study was to investigate the protective effect of qarahine against aspirin $(200 \mathrm{mg} / \mathrm{kg})$ and ethanol $(5 \mathrm{ml} / \mathrm{kg})$ induced gastric ulcer rat models. Methodology: The $\mathrm{pH}$ of stomach contents, numbers of lesions in gastric mucosa, severity score, ulcer index and percentage protection were determined. The stomachs mucosa was also evaluated for morphological changes. Three doses of qarahine $(250,500$ and $1000 \mathrm{mg} / \mathrm{kg}$ ) were evaluated. Omeprazole $(20 \mathrm{mg} / \mathrm{kg}$ ) was used as a standard drug. Results: Different doses of qarahine significantly raised $\mathrm{pH}$ and reduced the ulcer index in both aspirin and ethanol induced ulcerative rats. Qarahine $(500 \mathrm{mg} / \mathrm{kg}$ ) provided $29.9 \%$ and $32.9 \%$ protection in aspirin and ethanol-induced ulcer models. Histopathological studies validated the biochemical outcomes. Conclusion: This study suggested gastroprotective effect of qarahine which might be due to increase in gastric mucus secretions and mucus protective mechanisms. However, further studies are necessary to clarify the mechanisms of action of qarahine.
\end{abstract}

Key words: Qarahine, Gastroprotective, Aspirin, Ethanol, Ulcer index.

\section{INTRODUCTION}

Lesions in the linings of stomach and the first portion of duodenum is known as peptic ulcer. ${ }^{1}$ There are two main mechanisms, aggressive and defensive mechanisms in gastrointestinal tract (GIT) working at the same time. The aggressive mechanism causes secretion of acid and pepsinogen for the digestion of food while the defensive mechanism is supposed to protect the GIT linings by producing mucus and bicarbonate. Both mechanisms work bilaterally. ${ }^{2}$ When aggressive factors take a lead or defensive factors fail to work properly, the linings of the stomach and intestine are eroded by these factors and lead to ulceration of the GIT. Many drugs classes are being sold for the treatment of ulcer but despite all treatments, this disease cannot be eradicated completely. ${ }^{3}$
The currently used therapy to treat peptic ulcer has a number of side effects. The drugs of natural origin are among the safest and are used traditionally for centuries ago. ${ }^{4}$ Different products of natural drug combinations are available in market in Pakistan. Such combinations are also made to increase their effects against disease. Qarahine is a product of Hamdard laboratories, used for its activity against ulcer in Pakistan. It is helpful in the management of acute and chronic gastritis, amoebic and bacillary dysentery and diarrhoea. Its constituents are solely studied for its activity against ulcer but in combination, its effect is still needed for its scientific basis. Previous studies have shown that one component of qarahine, Glycyrrbiza glabra, exerted anti-ulcergenic effect by improving gastric defence mechanism. ${ }^{5}$
Submission Date: 21-07-2020; Revision Date: 15-12-2020; Accepted Date: 03-05-2021

DOI: 10.5530/ijper.55.3.155 Correspondence: Dr. Muhammad Naveed Mushtaq

Faculty of Pharmacy, The University of Lahore, Lahore, PAKISTAN.

Phone: +92-333-6794018

Email id: naveedmushtaq46@ gmail.com

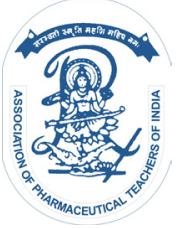

www.ijper.org 
The aim of the present study was to check the gastroprotective potential of qarahine in aspirin and ethanol induced gastric ulcer models. The $\mathrm{pH}$, total acidity, ulcer score and ulcer index of stomach were determined. Histopathological studies were also performed.

\section{MATERIALS AND METHODS}

\section{Composition of qarahine}

The study was performed on a poly herbal formulation namely qarahine. The constituents of qarahine with its quantities include (Quantity in $\mathrm{g} / 3 \mathrm{~g}$ ) Cochlospermum gossypium DC. (0.6150), Glycyrrbiza glabra Linn. (1.845), Koalinum ponderosum (0.1020), Lapis lazuli (0.039), magnesium silicate (0.051), Pistacia terebinthus Linn. (0.3090) and silicate of magnesia and ferrum (0.0390).

\section{Animals used}

Adult albino rats of either gender (160-220g) were purchased from The University of Lahore, Lahore. Animals were placed in animal house of Faculty of Pharmacy, The University of Lahore under stable circumstances. Animals were allowed freely to standard diet and tap water. Animal handling was performed as per guidelines of the National Research Council.

\section{Aspirin-induced ulcer}

Rats were randomly divided into six groups $(n=6)$. Group I named as the Normal control, was given vehicle (5 ml/kg 1\% gum acacia, orally). Group II, Disease control group, was administered with aspirin on $6^{\text {th }}$ day of experiment. Group III, IV and V received qarahine orally at doses of 250, 500 and $1000 \mathrm{mg} / \mathrm{kg}$ accordingly. Group VI was given with Standard drug (omeprazole) dissolved in propylene glycol in $20 \mathrm{mg} / \mathrm{kg}$ intraperitoneal. ${ }^{6}$ This treatment was extended for 5 days. The rats continued to fast for $24 \mathrm{~h}$ following the final dose of the last day, after that aspirin was given orally on $6^{\text {th }}$ day. Then, rats were dissected after six hours, stomachs were isolated and $\mathrm{pH}$ was determined. The magnifying lens was used to view the stomachs and stomach surfaces were observed for haemorrhage, blood vessels dilation, ulcer formation, rupturing, size and number of ulcers. The severity of ulcers was used to calculate ulcer index. ${ }^{7}$ The stomachs were placed in 10\% formalin.

\section{Ethanol-induced ulcer}

Rats were divided into six groups $(n=6)$. Group I was the Control group, received vehicle $(5 \mathrm{ml} / \mathrm{kg} ; 1 \%$ gum acacia orally). Group II was the disease control group and administered ethanol $(5 \mathrm{ml} / \mathrm{kg})$. Groups III, IV and $\mathrm{V}$ received qarahine orally at doses of 250, 500 and $1000 \mathrm{mg} / \mathrm{kg}$ accordingly. Group VI was standard drug control group and received omeprazole dissolved in propylene glycol in $20 \mathrm{mg} / \mathrm{kg} .{ }^{6}$ On $10^{\text {th }}$ day, overnight fasted rats were dissected out, stomachs were isolated and $\mathrm{pH}$ of gastric contents was recorded. The stomachs were incised along the lesser curvature. Stomachs were cleaned with distilled water and inner lining was observed with a naked eye. Stomachs were preserved in $10 \%$ formalin for microscopic analysis. ${ }^{7}$

\section{Ulcer score and ulcer index}

Numbers of ulcers were counted and summed up for each stomach. Ulcer size was measured with a magnifying lens, the ulcer (1 $\mathrm{mm}$ or less in size) was taken as determining spot both in aspirin and ethanol induced gastric ulcers. ${ }^{7}$

Whereas,

$0=$ no lesions

$1=$ haemorrhagic suffusions

$2=$ from 1 to 5 small ulcers up to $3 \mathrm{~mm}$ size

$3=$ many small ulcers more than 5 or 1 ulcer of more than $3 \mathrm{~mm}$

$4=$ many ulcers of more than $3 \mathrm{~mm}$

$5=$ perforated ulcers.

The ulcer index (UI) was calculated as given below;

$\mathrm{UI}=\mathrm{Un}+\mathrm{Us}+\left(\mathrm{Up}^{*} 10^{-1}\right)$

$\mathrm{Un}=$ average number of ulcers per animal

Us $=$ average number of severity of scores

$\mathrm{Up}=$ percentage of animals with ulcers.

And

$\%$ Protection $=(\mathrm{C}-\mathrm{T} / \mathrm{C}) \times 100$

whereas,

$\mathrm{C}=$ ulcer index in control group,

$\mathrm{T}=$ ulcer index in treated group ${ }^{8}$

\section{Determination of $\mathrm{pH}$}

Immediately as the stomachs were dissected, the $\mathrm{pH}$ of all the groups was checked by $\mathrm{pH}$ litmus paper with the gastric contents.

\section{Histopathological studies}

Stomachs were isolated and kept in a formalin $(10 \%)$. Following $24 \mathrm{hr}$ of fixation, the tissue was placed in paraffin. It was cut to a small piece and around 5 micron in size tissue was put on a glass slide and stained with hematoxylin-eosin.

\section{Statistical analysis}

Data were given as Mean \pm S.E.M. Results were analyzed by using One-Way ANOVA followed by Tukkey's test. Results were considered significant with $P<0.01$. 


\section{RESULTS}

\section{Effect of qarahine on aspirin induced ulcer}

The poly herbal qarahine in three doses $(250,500$ and $1000 \mathrm{mg} / \mathrm{kg})$ considerably $(P<0.001)$ reduced ulcer index and provided significant protection $(29.93 \%)$ in the pretreated rats as compared to disease control group (Table 1). Administration of qarahine increased the $\mathrm{pH}$ in aspirin induced ulcerative rats with the maximum effect produced at $250 \mathrm{mg} / \mathrm{kg}$ dose $(12 \%)$. However, the effect of qarahine at 500 and $1000 \mathrm{mg} / \mathrm{kg}$ doses on $\mathrm{pH}$ was not comparable with the standard drug treated group (Table 2).

\section{Histopathological studies}

Histopathology results showed that gastric mucosa and superficial epithelium was completely eroded in disease control group. In omeprazole pretreated rats, gastric mucosa and superficial epithelium were intact showing its gastro protective effect. Qarahine at $500 \mathrm{mg} / \mathrm{kg}$ dose demonstrated similar defense to that of omeprazole treated rats but $250 \mathrm{mg} / \mathrm{kg}$ dose and $1000 \mathrm{mg} / \mathrm{kg}$ doses had shown damage in gastric mucosa and superficial epithelium as shown in Figure 1.

\section{Effect of qarahine on ethanol induced ulcer}

Poly herbal qarahine in three doses $(250,500$ and $1000 \mathrm{mg} / \mathrm{kg})$ significantly $(P<0.001)$ decreased ulcer index and provided significant protection $(27.96,32.90$ and $31.18 \%$ ) respectively in the pretreated rats in comparison with disease control group. The outcomes were comparable to the standard drug treated group of rats (Table 3). Administration of qarahine increased $\mathrm{pH}$ in ethanol induced gastric ulcer rat model with the maximum effect produced at $500 \mathrm{mg} / \mathrm{kg}$ as shown in Table 4.

\section{Histopathological studies}

Histopathological studies showed that gastric mucosa and superficial epithelium were damaged in ethanol elicited gastric ulcer rats. Qarahine $(500 \mathrm{mg} / \mathrm{kg})$ has shown protective effect on gastric mucosa as shown in Figure 2.

\section{DISCUSSION}

Ulceration of gastric mucosa and uncontrolled gastric hyperacidity have posed serious health problems and affecting large population all over the world. ${ }^{9}$ The unevenness between aggressive and defensive mechanisms in the stomach leads to gastric mucosal injury. ${ }^{10}$ The protection of gastric mucosa and reduction of gastric acid production are the major approaches to treat gastric ulcer. Use of natural products and synthetic drugs is a well-known therapy of gastric ulcer disease
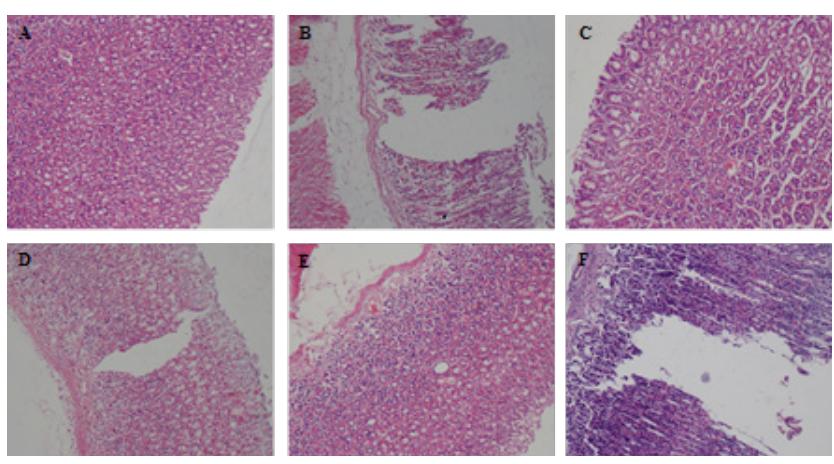

Figure 1: Histopathological studies of stomachs from Control (A), disease control (B), standard drug treatment (C), qarahine $(250,500$ and $1000 \mathrm{mg} / \mathrm{kg})(D),(E)$ and $(F)$ treated groups of rats in aspirin induced gastric ulcer model respectively.

(A) Superficial epithelium of stomach was normal with intact simple columnar cells, gastric glands were normal

(B) Mucosal epithelium was completely sloughed off, large sized ulcerative changes were found in mucosa, sub mucosa, muscularis externa and serosa (C) No haemorrhages were observed in mucosa, no pathological changes found in sub mucosa, muscularis externa and serosa (D) Moderate degenerative changes in gastric glands of mucosa, small sized ulcerative changes were found $(E)$ No hemorrhages were observed in mucosa. No pathological changes found in sub mucosa (F) Mild erosion of simple columnar epithelial cells of superficial epithelium, Mild degenerative changes in gastric glands of mucosa.

\begin{tabular}{|c|c|c|c|c|}
\hline \multicolumn{5}{|c|}{ Table 1: Effect of qarahine on aspirin induced gastric ulcer. } \\
\hline Treatments & $\begin{array}{c}\text { Number } \\
\text { of lesions }\end{array}$ & Severity score & $\begin{array}{c}\text { Ulcer } \\
\text { Index }\end{array}$ & $\begin{array}{c}\text { Percentage } \\
\text { protection }\end{array}$ \\
\hline Control & 0 & 0 & 0 & 0 \\
\hline Disease control & $37.67 \pm 0.2$ & $4.00 \pm 0.08$ & 14.17 & - \\
\hline $\begin{array}{c}\text { Standard drug treated } \\
\text { (Omeprazole } 20 \mathrm{mg} / \mathrm{kg})\end{array}$ & $0.67 \pm 0.04^{* * *}$ & $0.67 \pm 0.11^{* * *}$ & $6.83^{* * *}$ & $53.51^{* * *}$ \\
\hline Qarahine treated $(250 \mathrm{mg} / \mathrm{kg})$ & $6.33 \pm 0.07^{* * *}$ & $4.00 \pm 0.07$ & $11.03^{* * *}$ & $24.95^{* * *}$ \\
\hline Qarahine treated $(500 \mathrm{mg} / \mathrm{kg})$ & $1.33 \pm 0.03^{* * *}$ & $1.67 \pm 0.12^{* * *}$ & $10.30^{* * *}$ & $29.93^{\star * *}$ \\
\hline Qarahine treated $(1000 \mathrm{mg} / \mathrm{kg})$ & $2.33 \pm 0.04^{* * *}$ & $2.67 \pm 0.13^{* * *}$ & $10.50^{* * *}$ & $28.57^{* * *}$ \\
\hline
\end{tabular}

Data are expressed as Mean $\pm \operatorname{SEM}(n=5)$, Where $* * *=P<0.001$ vs disease control 
but complete cure from peptic ulcer is still undiscovered. After long-term therapies, there is recurrence of gastric ulcer and side effects are observed in patients. ${ }^{9}$ There is a big therapeutic challenge for the pharmacologists to establish the ulcer therapy. The present study intended to investigate the gastroprotective activity of qarahine, a poly herbal formulation used in Pakistan.

Aspirin and ethanol induced gastric ulcer models have been commonly used to evaluate the gastroprotective activity of plant extracts and drug formulations. Aspirin has been reported to damage the mucosal cells lining which triggers ulceration process. It causes gastric ulcer predominantly because of inhibition of COX-1 with subsequent decreased level of prostaglandins specially PGE1, PGE2 and PGI2. Moreover, aspirin interferes with mucus cell production as well as inhibition of bicarbonate and decreased mucus blood flow. ${ }^{11}$ Mechanism of induction of gastric ulcer by ethanol is not clearly known. However, lots of research studies have proved that oxidative stress, pro-inflammatory markers and apoptosis play key role in development of ulcer. Administration of ethanol causes direct damage to inner-most layer, resulting to gastric lesions, swelling, inflammation, blood spots and obstruction of blood vessels. ${ }^{12-14}$

In aspirin induced ulcer model, usage of qarahine (250, 500 and $1000 \mathrm{mg} / \mathrm{kg}$ ) significantly reduced the number of lesions (83.19, 96.46 and $93.81 \%$ ) and severity of gastric injuries (up to $60 \%$ ) with subsequent reduction in ulcer index. A significant decrease in the number of lesions by qarahine might be due to abatement of gastric acid secretion that is the major cause of ulcer. It was observed that qarahine $(500 \mathrm{mg} / \mathrm{kg})$ had more cytoprotective and antiulcer effect, which were comparable with omeprazole. Qarahine has increased the basicity of gastric contents as compared with disease control group. The findings of present study agree with the previous investigation. ${ }^{13}$ The increased production of histamine is directly proportional to the gastric acid secretions. Qarahine might inhibit the binding of histamine to $\mathrm{H}_{2}$ receptors. ${ }^{15}$ The histological

\begin{tabular}{|c|c|c|c|c|}
\hline \multicolumn{5}{|c|}{ Table 2: Effect of qarahine on ethanol induced gastric ulcer. } \\
\hline Treatments & $\begin{array}{c}\text { Number } \\
\text { of lesions }\end{array}$ & $\begin{array}{c}\text { Severity } \\
\text { score }\end{array}$ & $\begin{array}{c}\text { Ulcer } \\
\text { index }\end{array}$ & $\begin{array}{c}\text { Percentage } \\
\text { protection }\end{array}$ \\
\hline $\begin{array}{c}\text { Control } \\
\text { (Distilled water) }\end{array}$ & 0 & 0 & 0 & 0 \\
\hline Diseased (ethanol $5 \mathrm{ml} / \mathrm{kg}) /$ & $51.00 \pm 0.03^{* * *}$ & $4.00 \pm 0.03^{* * *}$ & $15.50^{* * *}$ & - \\
\hline $\begin{array}{c}\text { Standard drug treated } \\
\text { (Omeprazole 20mg/kg) }\end{array}$ & $1.33 \pm 0.05^{* * *}$ & $1.67 \pm 0.1^{* * *}$ & $10.30^{* * *}$ & $33.55^{* * *}$ \\
\hline $\begin{array}{c}\text { Qarahine treated } \\
(250 \mathrm{mg} / \mathrm{kg})\end{array}$ & $7.67 \pm 1.15^{* * *}$ & $4.00 \pm 1.3$ & $11.17^{* * *}$ & $27.96^{* * *}$ \\
\hline $\begin{array}{c}\text { Qarahine treated } \\
(500 \mathrm{mg} / \mathrm{kg})\end{array}$ & $2.33 \pm 1.01^{* * *}$ & $1.67 \pm 1.2^{* * *}$ & $10.40^{* * *}$ & $32.90^{* * *}$ \\
\hline $\begin{array}{c}\text { Qarahine treated } \\
(1000 \mathrm{mg} / \mathrm{kg})\end{array}$ & $4.00 \pm 0.04^{* * *}$ & $2.67 \pm 0.35^{\star * *}$ & $10.67^{* * *}$ & $31.18^{* * *}$ \\
\hline
\end{tabular}

Data are expressed as Mean $\pm \operatorname{SEM}(n=5)$, Where $* * *=P<0.005$ vs disease control.

\begin{tabular}{|c|c|}
\hline \multicolumn{2}{|c|}{$\begin{array}{c}\text { Table 3: Effect of qarahine on pH in aspirin induced } \\
\text { ulcer. }\end{array}$} \\
\hline $\begin{array}{c}\text { Treatments } \\
\text { pH } \\
\text { (Distilled water) }\end{array}$ & $6 \pm 0.02$ \\
\hline Disease control (aspirin $200 \mathrm{mg} / \mathrm{kg})$ & $2.0 \pm 0.2$ \\
\hline $\begin{array}{c}\text { Standard drug treated }(\text { Omeprazole } \\
20 \mathrm{mg} / \mathrm{kg})\end{array}$ & $5.25 \pm 0.01^{* * *}$ \\
\hline Qarahine treated $(250 \mathrm{mg} / \mathrm{kg})$ & $4.625 \pm 1.27^{* * *}$ \\
\hline Qarahine treated $(500 \mathrm{mg} / \mathrm{kg})$ & $3.85 \pm 1.1^{* * *}$ \\
\hline Qarahine treated $(1000 \mathrm{mg} / \mathrm{kg})$ & $3.95 \pm 0.9^{* * *}$ \\
\hline
\end{tabular}

Data are expressed as Mean $\pm \operatorname{SEM}(n=5)$, Where $* * *=P>0.001$ vs disease control
Table 4: Effect of qarahine on pH in ethanol induced ulcer.

\begin{tabular}{|c|c|}
\hline Treatments & pH \\
\hline $\begin{array}{c}\text { Control } \\
\text { (Distilled water) }\end{array}$ & $6 \pm 0.02$ \\
\hline Diseased control (ethanol $5 \mathrm{ml} / \mathrm{kg})$ & $2.3 \pm 0.04$ \\
\hline $\begin{array}{c}\text { Standard drug treated }(\text { omeprazole } \\
20 \mathrm{mg} / \mathrm{kg})\end{array}$ & $5.6 \pm 0.00^{\star * *}$ \\
\hline Qarahine treated $(250 \mathrm{mg} / \mathrm{kg})$ & $5.47 \pm 0.85^{\star \star *}$ \\
\hline Qarahine treated $(500 \mathrm{mg} / \mathrm{kg})$ & $5.675 \pm 0.08^{\star * *}$ \\
\hline Qarahine treated $(1000 \mathrm{mg} / \mathrm{kg})$ & $5.025 \pm 0.06^{\star \star *}$ \\
\hline
\end{tabular}

Data are expressed as Mean $\pm \operatorname{SEM}(n=5)$, Where $* * *=P>0.001$ vs disease control. 


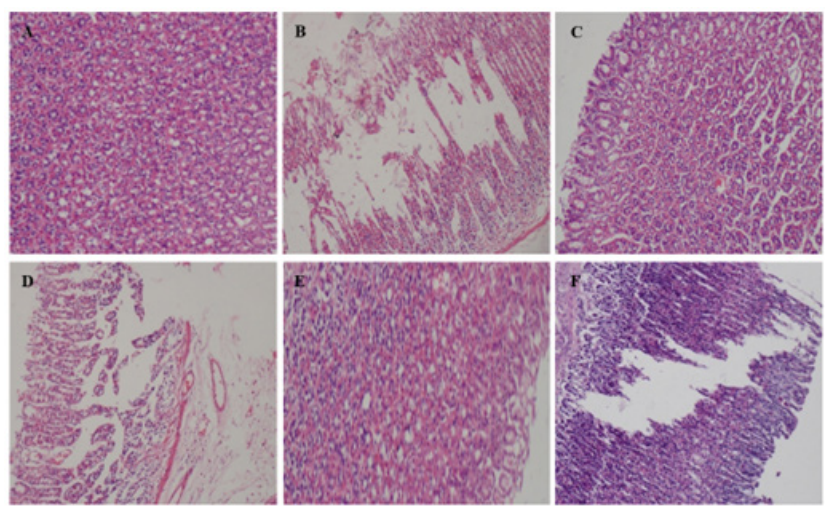

Figure 2: Histopathological studies of stomachs from Control (A), disease control (B), standard drug treatment (C), qarahine $(250,500$ and $1000 \mathrm{mg} / \mathrm{kg})(D),(E)$ and $(F)$ treated groups of rats in ethanol induced gastric ulcer model respectively. (A) Superficial epithelium of stomach was fine, no haemorrhage or ulcer was observed (B) Erosion of mucosal epithelium was found, lamina propria haemorrhages were found (C) Mild erosion of simple columnar epithelial cells of superficial epithelium (D) Moderate degenerative changes in gastric glands of mucosa, small sized ulcers were found (E) No hemorrhages and pathological changes were observed in mucosa (F) Mild degradation of simple columnar epithelial cells, few degenerative changes in gastric glands were found.

examinations also confirmed the gastroprotective effect of qarahine. Our results are in line with past studies. ${ }^{16}$ In ethanol induced ulcer model, pretreatment with qarahine $(250,500$ and $1000 \mathrm{mg} / \mathrm{kg}$ ) also significantly decreased the number of lesions (up to 95\%) and severity of gastric injury (up to $58 \%$ ) with subsequent reduction in ulcer index. Moreover, in qarahine pretreated group of rats, the $\mathrm{pH}$ has been changed to more alkaline as shown in Table 4. In disease control group, the histopathological study of the inner most layer presented the degradation of superficial epithelium, blood spots in lamina propria, patholgical developments in gastric glands, obstruction of blood vessels and gastric sores. Pretreatment with qarahine and omeprazole considerably improved these pathological changes in gastric mucosa and offered protection against ethanol induced gastric lesions. Our studies are in accordance with previous study. ${ }^{17}$

\section{CONCLUSION}

The findings of this study clearly showed the gastroprotective potential of qarahine in aspirin and ethaol-induced gastric ulcer models. It was observed that gastrorotective effect was in parallel in both models. It can be assumed that qarahine might produce its effect by enhancing prostaglandins synthesis, inhibiting oxidative stress and histaminic receptors stimulation.
However, further investigations are mandatory to find out the precise mechanism on molecular levels.

\section{ACKNOWLEDGEMENT}

We thank Professor Dr. Muhammad Shoaib Akhtar, University of Sargodha for his useful suggestions.

\section{CONFLICT OF INTEREST}

The authors declare that there is no conflict of interest.

\section{ABBREVIATIONS}

ANOVA: Analysis of variance; COX-1: cyclooxygenase-1; GIT: Gastrointestinal tract; PGE1: Prostaglandin E1; PGE2: Prostaglandin E2; PGI2: Prostaglandin I2; S.E.M: Standard error of mean.

\section{REFERENCES}

1. Kumar MS, Ghosh A, Kumar YA, Dileep K, Kumar SA. Kamadugha rasa an effective ayurvedic formulation for peptic ulcer: A review. Global J Res Med Plants and Indigen Med. 2014;3(1):24-32.

2. Toma W, de Souza Gracioso J, de ANDRADE FDP, Hiruma-Lima CA, Vilegas W, Brito. Antiulcerogenic activity of four extracts obtained from the bark wood of Quassia amara L.(Simaroubaceae). Biol Pharm Bull. 2002;25(9):1151-55.

3. Higuchi K, Fujiwara Y, Tominaga K, Watanabe T, Shiba M, Nakamura S, et al. Is eradication sufficient to heal gastric ulcers in patients infected with Helicobacter pylori? A randomized, controlled, prospective study. Aliment Pharmacol Ther. 2003;17(1):111-7.

4. Sanjoy PK, Shukla Y. Herbal medicine: Current status and the future. Asian Pac J Cancer Prev. 2003;4(4):281-8.

5. Jalilzadeh-Amin G, Najarnezhad V, Anassori E, Mostafavi M, Keshipour H. Antiulcer properties of Glycyrrhiza glabra L. extract on experimental models of gastric ulcer in mice. Iranian J Pharma Res. 2015;14(4):1163.

6. Thakuria B, Lahkar M, Bezbaruah BK. TOX-2 Evaluation of hepatoprotective activity of Vitex negundo linn. leaf extract against paracetamol induced liver damage in rats. Ind J Pharmacol. 2011;43:1.

7. Sen S, Asokkumar K, Umamaheswari M, Sivashanmugam AT, Subhadradevi V. Antiulcerogenic effect of gallic acid in rats and its effect on oxidant and antioxidant parameters in stomach tissue. Ind J Pharm Sci. 2013;75(2):149.

8. Minaiyan M, Ghassemi-Dehkordi N, Mohammadzadeh B. Anti-ulcer effect of Tripleurospermum disciforme (CA Mey) Shultz Bip on pylorus ligated (Shay) rats. Res Pharm Sci. 2007;1(1):15-21.

9. Olaleye S, Owoyele V, Odukanmi A. Antiulcer and gastric antisecretory effects of Landolphia owariensis extracts in rats. Nig J Physio Sci. 2008;23(1-2):23-6.

10. Banić M, Malfertheiner P, Babić Z, Ostojić R, Kujundzic M, Fatović-Ferenčić $\mathrm{S}$, et al. Historical impact to drive research in peptic ulcer disease. Dig Dis. 2011;29(5):444-53.

11. Halter F, Tarnawski A, Schmassmann A, Peskar B. Cyclooxygenase 2implications on maintenance of gastric mucosal integrity and ulcer healing: Controversial issues and perspectives. Gut. 2001;49(3):443-53.

12. Zakaria Z, Hisam EA, Rofiee M, Norhafizah M, Somchit M, Teh L, et al. In vivo antiulcer activity of the aqueous extract of Bauhinia purpurea leaf. J Ethnopharm. 2011;137(2):1047-54.

13. Sattar A, Abdo A, Mushtaq MN, Anjum I, Anjum A. Evaluation of Gastroprotective Activity of Myristica fragrans on Ethanol-induced Ulcer in Albino Rats. An Acad Bras Ciênc. 2019;91(2):e20181044.

14. Fahmy NM, Al-Sayed E, Michel HE, El-Shazly M, Singab AN. Gastroprotective effects of Erythrina speciosa (Fabaceae) leaves cultivated in Egypt against ethanol-induced gastric ulcer in rats. J Ethnopharmacol. 2020;248:112297. 
15. Banji D, Singh J, Banji OJ, Shanthamurthy M. Scrutinizing the aqueous extract of leaves of Pedalium murex for the antiulcer activity in rats. Pak J Pharm Sci. 2010;23(3)295-9.

16. AIRashdi AS, Salama SM, Alkiyumi SS, Abdulla MA, Hadi AHA, Abdelwahab $\mathrm{SI}$, et al. Mechanisms of gastroprotective effects of ethanolic leaf extract of
Jasminum sambac against $\mathrm{HCl} /$ ethanol-induced gastric mucosal injury in rats. Evid Based Complement Alternat Med. 2012;786426.

17. Abebaw M, Mishra B, Gelayee D. Evaluation of anti-ulcer activity of the leaf extract of Osyris quadripartita Decne. (Santalaceae) in rats. J Exp Pharmacol. 2017;9:1-11.

\section{PICTORIAL ABSTRACT \\ SUMMARY \\ - In our study, a polyherbal formulation qarahine was used to evaluate its claimed gastroprotective activity. \\ - Aspirin and ethanol were used to induce gastric ulcer models. \\ - Reduction in ulcer severity, ulcer score and ulcer index by qarahine showed its gastroprotective effect.
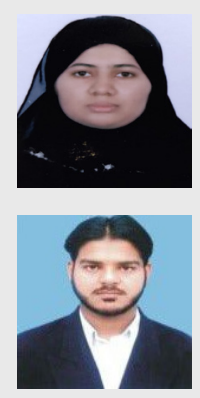 \\ Iqra Asad has recently completed her M.Phil in Pharmacology. Currently, She is working as a Quality Control Analyst in a Pharmaceutical industry. \\ Dr. Irfan Anjum is currently working as Assistant Professor of Pharmacology in Faculty of Pharmacy, The University of Lahore, Lahore. He is supervising postgraduate stdents for their research work. His doctoral research focussed on intracellular mechanisms of S1P in interstitial cystitis. \\ Mr. Haseeb Ahsan is working as a lecturer. $\mathrm{He}$ is a Ph.D scholar and carring out his research on inflammation and newly available phytochemicals. \\ Dr. M. Naveed Mushtaq is working as a Head, Department of Pharmacology, Faculty of Pharmacy, The University of Lahore, Lahore. His doctoral study focussed on evalaution of differentplant extracts in cardiovascular diseases. He is a Higher Education Commission of Pakistan Approved Ph.D Supervisor.

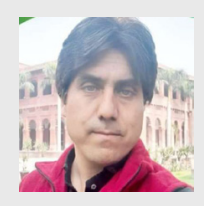 \\ Dr. Alamgeer is working as an Associate Professor of Pharmacology at University College of Pharmacy, University of Punjab, Lahore. He has supervised a number of M.Phil and Ph.D students in Pharmacology which are now working in different countries of the world. His research main focus is on cardiovascular.}

Cite this article: Asad I, Anjum I, Alamgeer, Ahsan H, Mushtaq MN. Evaluation of Gastroprotective Activity of Qarahine: A Polyherbal Formulation. Indian J of Pharmaceutical Education and Research. 2021;55(3):823-8. 